\title{
The antecryst compositional influence on Cretaceous alkaline lamprophyre dykes, SE Brazil
}

\author{
A influência composicional de antecristais em diques cretácicos de \\ lamprófiro alcalino, SE Brasil
}
Saulo Gobbo Menezes ${ }^{1}$, Rogério Guitarrari Azzone ${ }^{1 *}$, Gaston Eduardo Enrich Rojas ${ }^{1}$, Excelso Ruberti ${ }^{1}$, Renata Cagliarani ${ }^{1}$, Celso de Barros Gomes ${ }^{1}$, Luanna Chmyz ${ }^{2}$

\begin{abstract}
The question of whether the antecryst assemblage affects the bulk composition of lamprophyre dykes, and could be responsible for the compositional zonation between their centers and borders is addressed through a detailed study involving four monchiquite and camptonite dykes (basanites and tephrites) representative of the Arco de Ponta Grossa and Serra do Mar alkaline provinces. In them, antecrysts are interpreted as early-crystallized minerals that are no longer in equilibrium with their host-liquid, albeit still linked to the same magmatic system. They represent recycled crystals of earlier stages of the magmatic system at depth. The antecryst microtextures, such as zoned clinopyroxene megacrysts (augite cores and titanaugite rims) with partly corroded cores, olivine crystals with corroded rims surrounded by biotite coronas, chrome-spinel inclusions in clinopyroxene and olivine megacryst cores, and titanomagnetite crystals surrounded by biotite coronas, suggest chemical re-equilibrium with the matrix. The greatest antecryst cargo in these dykes is found in their centers. After subtracting the antecryst volume from the center analyses of each body, the calculated compositions are very similar to the border analyses. The mafic antecryst cargo of each occurrence proportionally leads to enrichment of $\mathrm{MgO}, \mathrm{FeO}, \mathrm{TiO}_{2}, \mathrm{CaO}$, compatible trace elements $(\mathrm{Cr}, \mathrm{Ni}$ and $\mathrm{Co})$, and depletion of $\mathrm{SiO}_{2}, \mathrm{~K}_{2} \mathrm{O}$, $\mathrm{Na}_{2} \mathrm{O}, \mathrm{Al}_{2} \mathrm{O}_{3}$ and incompatible trace elements ( $\mathrm{Ba}, \mathrm{Sr}$ and $\mathrm{REE}$ ). The whole-rock geochemical analyses of each dyke represent the combination of accumulated crystals and melt. The compositional zonation of the studied dykes is associated with the antecryst cargo rather than different magmatic pulses.
\end{abstract}

KEYWORDS: Antecrysts; Alkaline lamprophyres; Petrology; Geochemistry.
RESUMO: A questão de como a assembleia de antecristais influencia a composiçáa química de diques de lamprófiro e se esta pode ser responsável pelo zoneamento composicional entre núcleos e bordas é abordada por meio de um estudo detalhado em quatro diques de monchiquito e camptonito, representativos das provincias alcalinas Arco de Ponta Grossa e Serra do Mar. Nestes diques, os antecristais são interpretados como minerais cristalizados precocemente que náo se encontram mais em equilíbrio com o líquido que os carrega, mas que mantêm vínculo com o mesmo sistema magmático. Eles representam cristais reciclados de estágios magmáticos mais precoces em profundidade. As texturas dos antecristais, como megacristais zonados de clinopiroxênio (núcleos de augita e bordas de titanoaugita) com núcleos parcialmente corroídos, cristais de olivina corroídos nas bordas, envoltos por coronas de biotita, inclusão de cristais de cromoespinélio nos centros dos megacristais de clinopiroxênio e olivina e cristais de titanomagnetita envoltos por coronas de biotita, sugerem reequilíbrio com a matriz. Para os diques estudados, a maior carga de antecristais encontra-se em seus centros. Descontando-se o volume de antecristais nos centros de cada ocorrência, as composiçôes calculadas sáo muito semelhantes às globais das bordas. A carga de antecristais máficos de cada ocorrência, proporcionalmente, resulta em enriquecimento da composição global em $\mathrm{MgO}, \mathrm{FeO}, \mathrm{TiO}, \mathrm{CaO}$, elementos traços compativeis ( $\mathrm{Cr}$, $\mathrm{Ni}$ e Co), e ao empobrecimento em $\mathrm{SiO}_{2}, \mathrm{~K}_{2} \mathrm{O}, \mathrm{Na}_{2} \mathrm{O}, \mathrm{Al}_{2} \mathrm{O}_{3}$ e traços incompativeis ( $B a$, Sr e ETR). Assim, as análises geoquimicas globais de cada dique são representativas da combinação de cristais acumulados e magma. Além disso, as variaçôes composicionais relativas às zonalidades dos diques estudados parecem estar predominantemente relacionadas à carga de antecristais e não a diferentes pulsos magmáticos.

PALAVRAS-CHAVE: Antecristais; Lamprófiros alcalinos; Petrologia; Geoquímica.

\footnotetext{
${ }^{1}$ Geosciences Institute, Universidade de São Paulo - USP, São Paulo (SP), Brazil. E-mail: saulo.menezes@usp.br; rgazzone@usp.br; gastonenrich@usp.br; exrubert@usp.br; renata.cagliarani@usp.br; cgomes@usp.br

${ }^{2}$ Postgraduation Program in Geology, Universidade Federal do Paraná - UFPR, Curitiba (PR), Brazil. E-mail: luannachmyz@hotmail.com

*Corresponding author.

Manuscrito ID: 30188. Recebido em: 10/22/2014. Aprovado em: 02/13/2015.
} 


\section{INTRODUCTION}

Chemical composition of primitive basic alkaline dykes may be considered representative of low-degree mantle melts. The study of such dykes enables the identification of their mantle source characteristics, which include geochemical signatures, large- and small-scale heterogeneities, and metasomatic processes (e.g., Comin-Chiaramonti et al. 1997; Gibson et al. 1999). However, some of them may also record processes of magmatic evolution that mask their pristine signatures, like crystal-liquid fractionation, wall-rock assimilation and liquid immiscibility, among others (e.g., Thompson et al. 1998; Trumbull et al. 2003; Vichi et al. 2005). Indeed, the most primitive rocks of a dyke swarm frequently have somewhat more evolved compositions than the primitive melts assessed in experimental studies (Comin-Chiaramonti et al. 1997).

Detailed studies are necessary for the petrologic characterization of small tabular bodies. In particular, effects of megacrysts on the bulk chemical composition and their meaning have been widely discussed, especially in porphyritic varieties (Ubide et al. 2012; Larrea et al. 2012). Recently, the term 'antecrysts' has been systematically used (e.g., Charlier et al. 2005; Davidson et al. 2007; Jerram \& Martin 2008) referring to a specific crystal type that differs from those identified as phenocrysts (larger early-crystallized phases that are in equilibrium with the liquid) and xenocrysts (crystals that are foreign to the magmatic liquid and have no genetic association with it). Antecrysts may be defined as crystals that did not crystallize directly from the host magma in which they are contained, although they maintain a genetic relationship with the same system. For example, they may be a representation of a previous stage of magmatic evolution and are no longer in chemical equilibrium with the fractionated liquid that carries them.

This issue is of the utmost importance when studying lamprophyres, which are porphyritic rocks with mesocratic to melanocratic characteristics (Rock 1991), because they contain a large amount of mafic megacrysts. Alkaline lamprophyre dykes of basanitic composition are recognized in several Mesozoic-Cenozoic alkaline occurrences in the South American platform. For example, this is true in the case of Juquiá (Beccaluva et al. 1992), Lages (Traversa et al. 1996), Monte de Trigo (Enrich et al. 2009), and São Sebastião (Bellieni et al. 1990) occurrences. Although some of these dykes approach the composition of primary melts (Traversa et al. 1996; Brotzu et al. 2005), others were not simply treated as melts and their compositions were attributed to a combination of basic alkaline melt and accumulated mafic crystals (Beccaluva et al. 1992).
The motivation for this study has been to understand the meaning of the zoned lamprophyre dykes and their association with the megacryst population. For this purpose, four dykes from different locations within the Arco de Ponta Grossa and Serra do Mar alkaline provinces related to the Mesozoic-Cenozoic magmatism of the southeastern part of the Brazilian Platform were chosen for a detailed petrographic and geochemical study.

\section{MAGMATIC CONTEXT}

More than 100 occurrences of alkaline and alkaline-carbonatite Mesozoic-Cenozoic rocks have been reported in the South-central portion of the Brazilian Platform and were clustered into various provinces (Riccomini et al. 2005). Most of them are intrusive suites of less than $100 \mathrm{~km}^{2}$, sometimes associated with dyke swarms (Morbidelli et al. 1995). The abundance of evolved lithologies is noteworthy, including nepheline syenite and syenite, as in São Sebastião, Itatiaia, Poços de Caldas, Banhadão occurrences (Bellieni et al. 1990; Brotzu et al. 1997; Ulbrich et al. 2005; Ruberti et al. 2012). Cumulate associations often formed by clinopyroxenites and members of the ijolitic series with dunites and carbonatites to a lesser extent are also found like in Jacupiranga, Juquiá, Ponte Nova, Salitre and Tapira massifs (Beccaluva et al. 1992; Azzone et al. 2009; Gomes et al. 2011; Barbosa et al. 2012; Brod et al. 2013).

Alkaline mafic dykes happen more restrictedly in this context. Usually, they present less-evolved characteristics and are classified as lamprophyres. They normally exhibit a porphyritic texture with a fine-grained to aphanitic matrix. Chemically, they have a composition that corresponds to alkaline basalts, basanites, and nephelinites. These dykes are particularly abundant in the alkaline provinces of Arco de Ponta Grossa and Serra do Mar (Beccaluva et al. 1992; Alves et al. 1992; Garda et al. 1995; Valente 1997; Thompson et al. 1998; Gibson et al. 1999; Azzone et al. 2009; Enrich et al. 2009; Gomes et al. 2011). They mostly occur near or crosscutting the alkaline intrusive suites.

\section{GEOLOGICAL ASPECTS}

Four alkaline lamprophyre dykes from different locations in the alkaline provinces of Arco de Ponta Grossa and Serra do Mar were selected for this study. The locations of these dykes are shown in Fig. 1 and listed in Table 1. Their descriptions are further shown. 


\section{Dyke 1}

It occurs in situ, N-NW-oriented, showing irregular shape, and thickness ranging from $20 \mathrm{~cm}$ to $1.2 \mathrm{~m}$ with strong zoning between the center and border. This dyke has grey to black color, massif structure, and panidiomorphic porphyritic texture, with a fine-grained matrix and a few globular structures mainly filled with carbonates in the central and intermediate zones of the dyke. Medium-grained mafic megacrysts are found at higher concentrations in the central portions. The borders show a microphaneritic to aphanitic matrix, whereas the center exhibits a fine-grained matrix. The dyke intrudes into syenogranites of the Guaraú massif, Graciosa province (Precambrian; Faleiros \& Pavan 2013), and it was sampled in an abandoned quarry. At a $0.5 \mathrm{~m}$ distance, a diabase dyke of tholeiitic affinity is parallel to this one. No contact relationships were seen between the two dykes.

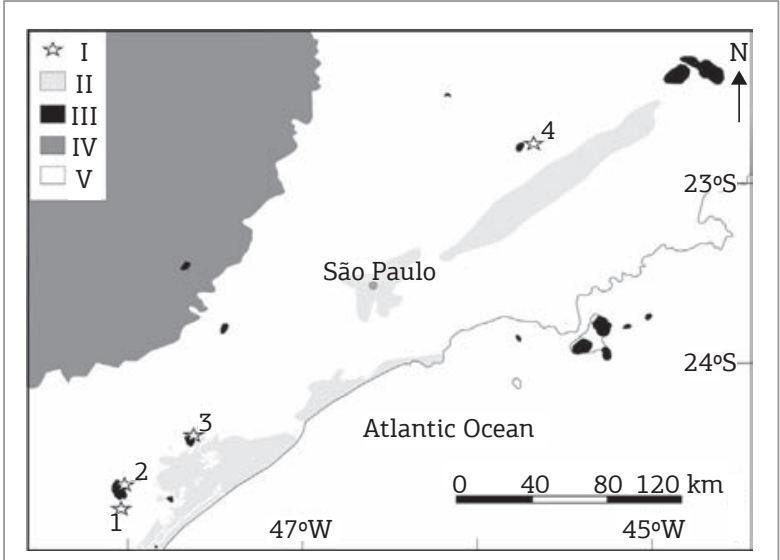

I: Selected alkaline dykes. II: Sediments or sedimentary rocks associated with rift basins (Cenozoic); III: Alkaline complexes (Mesozoic-Cenozoic); IV: Sedimentary rocks of Paraná Basin (Ordovician-Silurian); V: Crystalline Basement, Brasília and Ribeira orogenic belts (Precambrian). Simplified from Schobbenhaus et al. (2004).

Figure 1. Location and geological setting of the studied alkaline dykes. Numbers 1 to 4 refer to the numbering used in the text.

\section{Dyke 2}

The second dyke occurs in situ, NW-oriented, showing irregular shape, variable thickness ranging from 20 to $60 \mathrm{~cm}$, and well-marked zoning between the center and border. This dyke exhibits grey color, massive structure, and porphyritic texture, with medium- to coarse-grained mafic megacrysts in a fine-grained matrix. There is a well-defined contact, albeit slightly sinuous to irregular, between the center and border of the dyke. There is no significant variation in the relative ratio of megacrysts between the center and border zone. The dyke was sampled on a hillock with in situ outcrops, discontinuous flagstones, and a few boulders slightly tilted in the same place. It is intruded into the Jacupiranga alkaline-carbonatitic complex (Cretaceous; Gomes et al. 2011) and cuts a coarse-grained syenite, which has cumulate alkali-feldspar megacrysts, and a fine- to medium-grained theralite.

\section{Dyke 3}

It occurs along secondary dirt road, close to the drainage network and next to in situ outcrops of olivine clinopyroxenites. Although no contact relationships or zoned structures were observed, this rock was presumably intrusive into the olivine clinopyroxenite of the North-central portion of the Juquiá alkaline carbonatitic complex (Cretaceous; Gomes et al. 2011). This is most likely the same occurrence as the one analyzed by Beccaluva et al. (1992) and Gibson et al. (1999), based on the location and previous descriptions. This dyke exhibits grey color, massive structure and porphyritic to glomeroporphyritic texture, and contains coarse-grained mafic megacrysts in a fine- to medium-grained matrix.

\section{Dyke 4}

Dyke 4 occurs in situ, with 1-m-thickness and E-W orientation. This dark-grey massive rock presents aphanitic texture in its border and a porphyritic texture in the center, in a phaneritic fine-grained matrix. Medium- to coarse-grained mafic megacrysts and globular structures, mostly filled

Table 1. Geological data and location of the alkaline dykes selected for this study.

\begin{tabular}{l|c|c|c|c}
\hline & Coordinates (UTM) & $\begin{array}{c}\text { Alkaline Province } \\
\text { (Riccomini et al., 2005) }\end{array}$ & $\begin{array}{c}\text { Type of } \\
\text { outcrop }\end{array}$ \\
\hline Dyke 1 & 22J0794101/7255729 & APG & in situ & $\begin{array}{c}\text { Syenogranites of the Guaraú Massif, } \\
\text { Graciosa Suite (Precambrian) }\end{array}$ \\
\hline Dyke 2 & 22J0791201/7268628 & APG & in situ & $\begin{array}{c}\text { Nepheline-bearing syenites and theralites of the } \\
\text { Jacupiranga Alkaline-Carbonatite complex (Mesozoic) }\end{array}$ \\
\hline Dyke 3 & 22J0226842/7299321 & APG & blocks & $\begin{array}{c}\text { Olivine clinopyroxenites of the Juquiá } \\
\text { Alkaline-Carbonatite complex (Mesozoic) }\end{array}$ \\
\hline Dyke 4 & 23K0437277/7480569 & SM-N & in situ & $\begin{array}{c}\text { Granites of the Paraisópolis } \\
\text { Complex (Precambrian) }\end{array}$ \\
\hline
\end{tabular}

APG: Arco de Ponta Grossa; SM-N: Serra do Mar - North Sector. Specific data on wall rocks may be found in Cavalcante et al. (1979), Beccaluva et al. (1992) and Faleiros \& Pavan (2013). 
with white carbonates, occur in the central region. This dyke intrudes into locally mylonitized granites/gneisses of Paraisópolis Complex (Precambrian; Cavalcante et al. 1979).

\section{MATERIALS AND METHODS}

For each dyke, five to eight samples were collected, both in the center and in the border of the dykes. All samples were described under a petrographic microscope. Modal analyses were performed on representative samples of center and border of the dykes, according to the methodology proposed by Chayes (1956). Descriptions were complemented with backscattered electron images obtained at the Laboratory of Scanning Electron Microscopy of the Institute of Geosciences, Universidade de São Paulo (USP), in Brazil. A LEO 4401 apparatus, operating with acceleration voltage of $20 \mathrm{kV}$, and probe current of 6 to $8 \mathrm{nA}$, was used.

Whole-rock samples presenting size equivalent to a cube with a face at least 10 times that of the largest crystal were considered for the geochemical analysis (Potts 1987). No separation between the crystal populations present in the samples was carried out. Their analyses of major and certain trace elements through X-ray fluorescence were conducted at the X-ray Fluorescence Laboratory of Geoanalítica-USP Facility using an automatic Philips $\mathrm{x}$-ray spectrometer, model PW2400. Further details of the preparation can be found in Mori et al. (1999). Other trace elements were analyzed by inductively coupled plasma mass spectrometry (ICP-MS) in the Chemistry and ICP Laboratory of Geoanalítica-USP Facility, which is equipped with a Perkin Elmer spectrometer, model ELAN 6100 DRC. A 100-mg aliquot was collected from each sample for etching via microwave. More details on the preparation can be found in Navarro et al. (2008).

\section{PETROGRAPHY}

\section{General aspects}

Table 2 shows the modal analysis for each dyke and their different zones. The petrographic analyses sought to separate the main crystal populations. For this purpose, only descriptive terminology, based on the terms megacrysts, microcrysts and matrix, was used. The terms phenocrysts, antecrysts and xenocrysts are interpretively used according to their genetic connotations. The megacrysts represent only crystals with abnormal large size compared to the others (> 10 times the average size of the matrix crystals). Microcrysts represent crystals from five to ten times the average one.

\section{Dyke 1}

Monchiquite ( $c f$. Le Maitre 2002). This dyke is also classified as monchiquitic basanite ( $c f$. Rock 1991), given the greater amount of mesostasis compared to plagioclase and the lower concentration of hydrous mafic minerals compared to anhydrous mafic minerals. The texture is porphyritic, panidiomorphic, varying to vitrophyric. Fluidal structure occurs in contact with the wall rock, mainly marked by the orientation of zoned augite microcrysts.

Euhedral megacrysts vary in size from 0.5 to $2.5 \mathrm{~mm}$, consisting of olivine, augite, and biotite and ranging from -5 vol. $\%$ in the border to -25 vol. $\%$ in the center of the dyke. Clusters of megacrysts are found both in samples from the center of the dyke and at contact with wall rocks. Augite megacrysts predominate in the dyke border, whereas olivine and biotite megacrysts prevail in the center. Internal zoning structures are common in augite and biotite and may occur in some olivine crystals too. There are augite crystals with corroded cores and occasional corrosion features along the borders (Fig. 2). The olivine megacrysts are commonly

Table 2. Modal mineralogical compositions of the alkaline lamprophyre dykes shown in this study.

\begin{tabular}{|c|c|c|c|c|c|c|c|}
\hline & \multicolumn{2}{|c|}{ Dyke 1} & \multicolumn{2}{|c|}{ Dyke 2} & \multirow{2}{*}{$\begin{array}{c}\text { Dyke } 3 \\
\text { bl }\end{array}$} & \multicolumn{2}{|c|}{ Dyke 4} \\
\hline & c & b & c & b & & c & b \\
\hline Classification & $\begin{array}{c}\text { Monchiquitic } \\
\text { Basanite }\end{array}$ & $\begin{array}{c}\text { Monchiquitic } \\
\text { Basanite }\end{array}$ & $\begin{array}{c}\text { Campto- } \\
\text { monchiquite }\end{array}$ & $\begin{array}{c}\text { Campto- } \\
\text { monchiquite }\end{array}$ & $\begin{array}{l}\text { Camptonitic } \\
\text { Basanite }\end{array}$ & $\begin{array}{l}\text { Camptonitic } \\
\text { Basanite }\end{array}$ & $\begin{array}{c}\text { Camptonitic } \\
\text { Basanite }\end{array}$ \\
\hline No. Points & 1026 & 1045 & 987 & 914 & 1050 & 1560 & 1040 \\
\hline Olivine (\%) & 10.8 & & 2.2 & 0.2 & 15.2 & 12.8 & 8.8 \\
\hline Clinopyroxene & 41.5 & 35.9 & 36.0 & 29.9 & 31.8 & 25.3 & 34.7 \\
\hline $\begin{array}{l}\text { Felsic minerals + } \\
\text { Felsic mesostasis/Glass }\end{array}$ & 10.9 & 36.0 & 23.8 & 30.6 & 26.4 & 20.8 & 28.2 \\
\hline Amphibole & 4.6 & 0.6 & & 0.2 & & 8.0 & 9.7 \\
\hline Biotite & 19.3 & 15.1 & 32.6 & 30.3 & 15.0 & & \\
\hline Opaques & 4.7 & 5.5 & 5.4 & 8.8 & 10.8 & 14.6 & 12.7 \\
\hline $\begin{array}{l}\text { Accessories + } \\
\text { Hydrothermal Assemblage }\end{array}$ & 8.2 & 7.0 & & & 0.9 & 18.5 & 5.9 \\
\hline
\end{tabular}

The ratios, expressed as percentages, were calculated by counting points (Chayes 1956). The accessory + hydrothermal assemblage is characterized by apatite, carbonate, titanite, actinolite, analcime, and sulfides. Classification according to Rock (1991). Abbreviations: c, center; b, border, bl, block. 
altered or corroded. Chrome-spinel and titanomagnetite inclusions usually occur in the augite and olivine crystals.

The microcryst and matrix proportions range from -75 to -95 vol.\% at the center and border zones, respectively.
The microcrysts predominantly occur in the center of the dyke and range from 0.1 to $0.5 \mathrm{~mm}$. They consist of augite, biotite, titanomagnetite and kaersutite and have euhedral to subhedral habit. The matrix minerals have crystal size
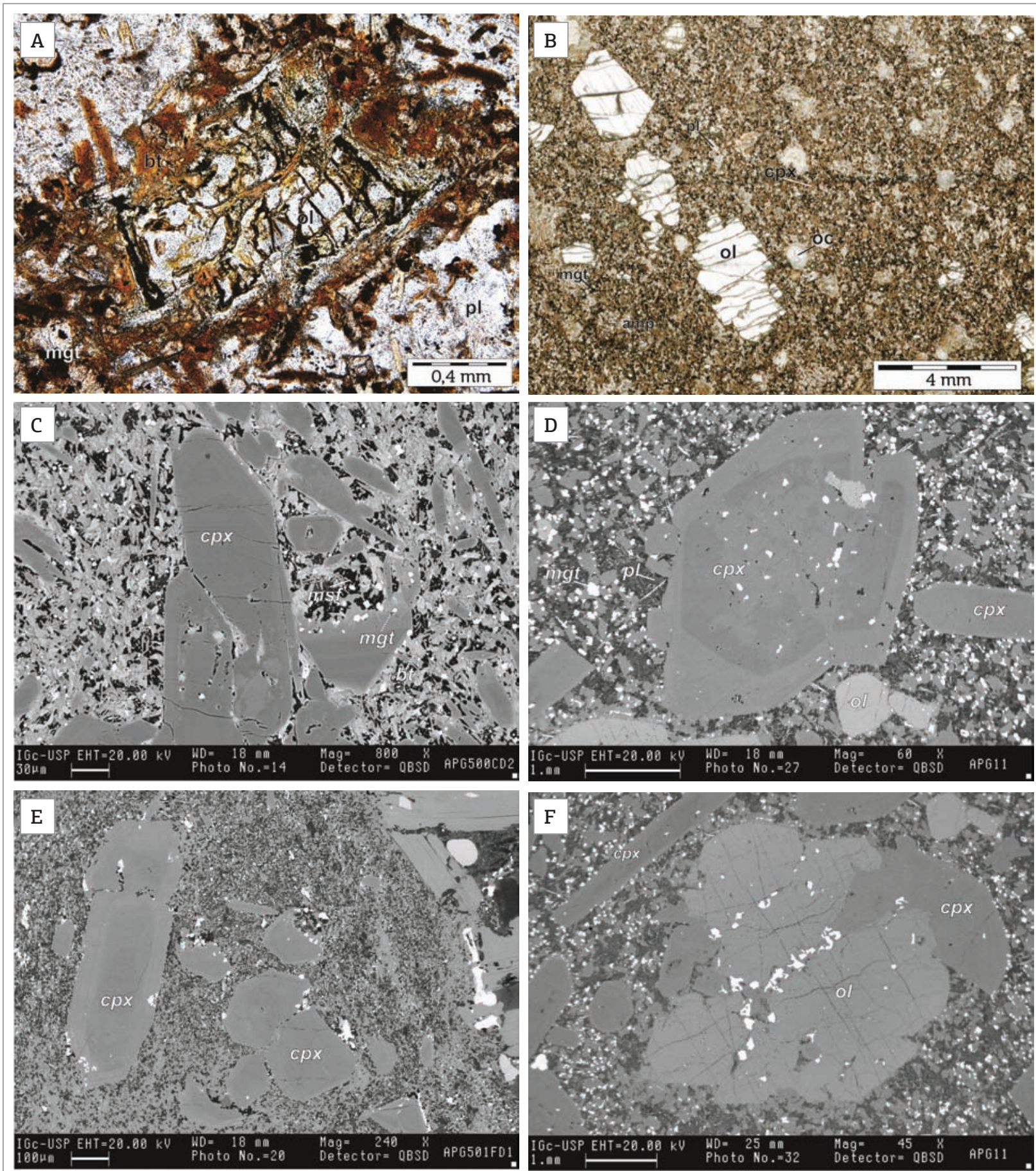

amp: amphibole; bt: biotite; cpx: clinopyroxene; mgt: magnetite; msf: felsic mesostasis; pl: plagioclase; oc: ocellar structures; ol: olivine.

Figure 2. (A) Photomicrograph of partly corroded olivine megacryst, with biotite in coronitic texture - dyke 2 (polarized light). (B) Photomicrograph of olivine megacrysts with embayment regions, which are suggestive of reactive contact with magma - dyke 4 (polarized light). (C) Backscattered electron micrograph of zoned clinopyroxene megacrysts with corrosion textures - dyke 1. (D) Backscattered electron micrograph of a zoned clinopyroxene megacryst, with different overgrowth stages and partly reequilibrated core - dyke 3. (E) Backscattered electron micrograph of zoned clinopyroxene megacrysts with oscillatory and concentric zonings in crystal clusters - dyke 2. (F) Backscattered electron micrograph of a round-shaped cluster of olivine and clinopyroxene megacrysts - dyke 3 . 
smaller than $0.1 \mathrm{~mm}$ and consist of augite, biotite, titanomagnetite, apatite, alkali feldspar, plagioclase, analcime, and glass. They are subhedral to anhedral, although some augite, apatite and biotite have euhedral habit. Elongate alkali feldspar and interstitial analcime in equivalent ratios compose felsic mesostasis, possibly associated with late magmatic or hydrothermal glass alteration processes.

\section{Dyke 2}

Monchiquite ( $c f$. Le Maitre 2002). This dyke can also be classified as campto-monchiquite ( $c f$. Rock 1991), given the occurrence of biotite as an essential mineral and the greater amount of felsic mesostasis/glass compared to plagioclase. The texture is porphyritic panidiomorphic varying to vitrophyric, and includes transitions to fluidal structure when in contact with wall rocks.

Euhedral olivine and augite are megacrysts ranging from -5 to -7 vol. $\%$, with greater concentrations in the central zone. Their grain size varies from 0.5 to $3.0 \mathrm{~mm}$. Some sporadic biotite megacrysts and clusters of augite megacrysts with cumulate textures occur in the central zone of the dykes. Augite megacrysts are significantly more predominant than olivine in the border zones. The presence of zoned structures is common in augite megacrysts and resorption textures occur in some cases. Augite and olivine megacrysts present inclusions of oxides (chrome-spinel, spinel and titanomagnetite). Olivine megacrysts are commonly corroded (Fig. 2), usually mantled by brown biotite and apparently associated with changes in the $\mathrm{SiO}_{2}$ activity of the system (Parson et al. 1991).

The microcryst and matrix proportions range from $\sim 97$ to -95 vol. $\%$ in the center and border of the dyke, respectively. The microcrysts consist of titanaugite, biotite, and titanomagnetite. They are between 0.1 and $0.4 \mathrm{~mm}$ in size and have euhedral to subhedral habit. The matrix minerals are up to $0.1 \mathrm{~mm}$ and are represented by euhedral to subhedral apatite, titanaugite, kaersutite, plagioclase and alkali-feldspar, granular to interstitial titanomagnetite, and anhedral analcime. Titanaugite with or without internal zoning is particularly abundant in the rock matrix, and may show corroded cores.

\section{Dyke 3}

Camptonite ( $c f$. Le Maitre et al. 2002). This dyke is also classified as a camptonitic basanite (cf. Rock 1991), given the smaller occurrence of hydrous mafic minerals compared to anhydrous mafic minerals as megacrysts. The predominant texture in all samples is porphyritic panidiomorphic. The geological situation precludes considerations on petrographic differences between the center and borders of the dyke.
The megacrysts correspond to -35 vol.\% and have sizes ranging from 0.5 to $7.0 \mathrm{~mm}$, with a predominance of augite megacrysts over olivine. Both exhibit euhedral habit, internal zoning and chrome-spinel microinclusions. The augite crystals show partly corroded cores and replacement with either titanaugite or matrix minerals (Fig. 2). The olivine crystals are surrounded by a thin biotite corona. Clusters of zoned olivine and augite megacrysts with rounded shapes (Fig. 2) are common.

Microcrysts and the matrix correspond to -65 vol.\%. The microcrysts have sizes ranging from 0.3 to $0.6 \mathrm{~mm}$ and consist of titanaugite, plagioclase and, subordinately, titanomagnetite. The matrix size reaches up to $0.3 \mathrm{~mm}$ and consists of titanaugite, plagioclase, alkali-feldspar, titanomagnetite, apatite, and biotite. The clinopyroxene habit is predominantly euhedral to subhedral, whereas the other minerals vary from subhedral to anhedral and interstitial. Biotite predominantly mantles both as olivine megacrysts and as titanomagnetite microcrysts found in contact with interstitial feldspars of the matrix.

The classification of this dyke as a lamprophyre is somewhat dubious. Biotite, the only hydrous mafic present in this occurrence, is preferentially associated with reaction context, including titanomagnetite or olivine megacryst surroundings. The formation of biotite should thus be associated with local changes in the $\mathrm{O}_{2}$ fugacity and/or $\mathrm{SiO}_{2}$ activity of the system (Parson et al. 1991). Consequently, this might be a case of an apocryphal lamprophyre, according to Rock (1991).

\section{Dyke 4}

Camptonite ( $c f$. Le Maitre et al. 2002). This dyke may be classified as a camptonitic basanite ( $c f$. Rock 1991), given the concentration of hydrous mafics as minor constituents and lower amount of glass/mesostasis compared to plagioclase. The dyke is zoned and shows a coarser grain-size in its central portion than in the border area. It usually has panidiomorphic porphyritic inequigranular texture, defined by the presence of olivine megacrysts (up to $~ 10$ vol. $\%$ in the central area) in a fine-grained matrix (Fig. 2).

The central portion of the dyke features a holocrystalline panidiomorphic texture, with the presence of olivine megacrysts in a fine-grained matrix $(0.1$ to $0.4 \mathrm{~mm})$. The olivine megacrysts predominantly appear as pseudomorphs with mean sizes from 1 and $2 \mathrm{~mm}$, and olivine also occurs as microcrysts. Clusters of augite microcrysts are uncommon, but present $(0.6$ to $0.75 \mathrm{~mm})$. The augite crystals are commonly zoned with Ti-augite rims. Olivine, kaersutite and augite microcrysts are usually euhedral to subhedral. The matrix exhibits an intergranular texture. It consists of plagioclase, kaersutite, augite and opaque minerals with 
acicular apatite as an accessory mineral. The latter is always associated with plagioclase.

The intermediate portion and a border sample have fine inequigranular texture $(0.2$ to $0.5 \mathrm{~mm})$ without megacrysts, albeit with the same ratio of microcrysts and matrix as the center. The other border samples have inequigranular hypocrystalline textures. The matrix consists of a dark brownish mass of very thin $(<<0.1 \mathrm{~mm})$ material composed of partly altered glass. Olivine $(0.1$ to $0.6 \mathrm{~mm})$, as pseudomorphs, and augite megacrysts are also observed. Locally, sub-centimetric granitic xenoliths were found in the border zone. The matrix surrounding xenoliths is finer and has a high percentage of opaque minerals when compared to the rest of the rock. The xenoliths also include large amounts of opaque minerals in greater percentage than the wall rocks and are percolated by carbonates.

\section{Globular structures and segregations}

Dyke 1 has amoeboid to globular-shape microstructures (ocelli) that are usually $0.5 \mathrm{~mm}$ in size. These structures feature zoning that consist of dolomite in the rims and calcite in the cores (Fig. 3). Matrix minerals are sometimes found mantling them. Amoeboid to globular microstructures occur both in the borders and centers of dyke 2. They either have zoning with potassium feldspar and albite in the rims and carbonates in the cores or occur without zoning, consisting predominantly of potassium feldspar and albite (Fig. 3) including subordinate biotite, apatite, and titanomagnetite. The matrix minerals mantle these microstructures in both cases. The circular to amoeboid microstructures in dyke 3 are much less frequent. They consist of carbonates, analcime, and biotite and commonly alter the local texture of the rock, because the crystals of the matrix mantle these microstructures. The globular structures in dyke 4 have an average size ranging from 2 to $3 \mathrm{~mm}$. Carbonates are predominant, and analcime and spherulites are less common. The latter consists of clusters of phyllosilicates, including serpentine. Some zonation occurs around the ocelli.

The analyzed ocelli are mostly interpreted as structures derived from the segregation of late-stage magma. The key factors supporting this interpretation include: exhibiting round to sinuous shapes; the interiors have mineralogical-compositional zoning; the matrix texture is locally modified, with hydrous mafic crystals of the matrix tangent to the structures; and the mineralogical composition either consists of analcime and carbonate or feldspars, always associated with late-stage magmatic assemblage. Such features are similar to those observed by Foley (1984) and Rock (1991) for the same kind of process.

\section{Deuteric/hydrothermal alterations}

The mineral assemblage derived from deuteric and/or hydrothermal alterations is not significant among the studied dykes. It consists of epidote, serpentine, muscovite, titanite, actinolite, and carbonates and occurs in association with matrix minerals or olivine and augite megacrysts. Apparently, actinolite is always associated with augite alteration in dyke 1 (Fig. 4), especially in the rims of this mineral in contact with felsic minerals of the matrix. Olivine crystals occur partly or fully replaced in dykes 4 and 1 as well, and these crystals are replaced by carbonate, muscovite, biotite, epidote, and serpentine (Fig. 4).

\section{GEOCHEMISTRY}

Geochemical data of the dykes selected for this study are summarized in Table 3, which includes the results for major,

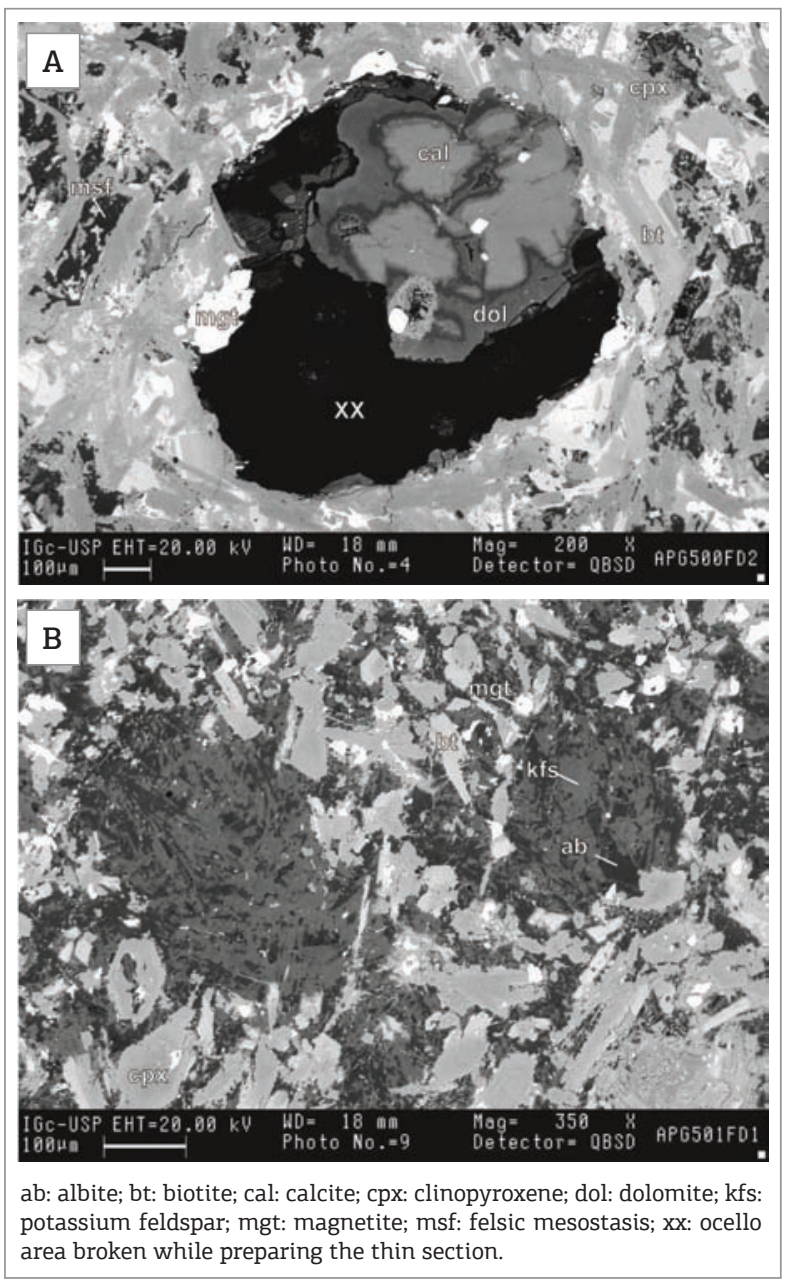

Figure 3. Backscattered electron micrographs of globular structures. (A) Carbonatic ocello, dyke 1. (B) Feldspathic ocello, dyke 2. 

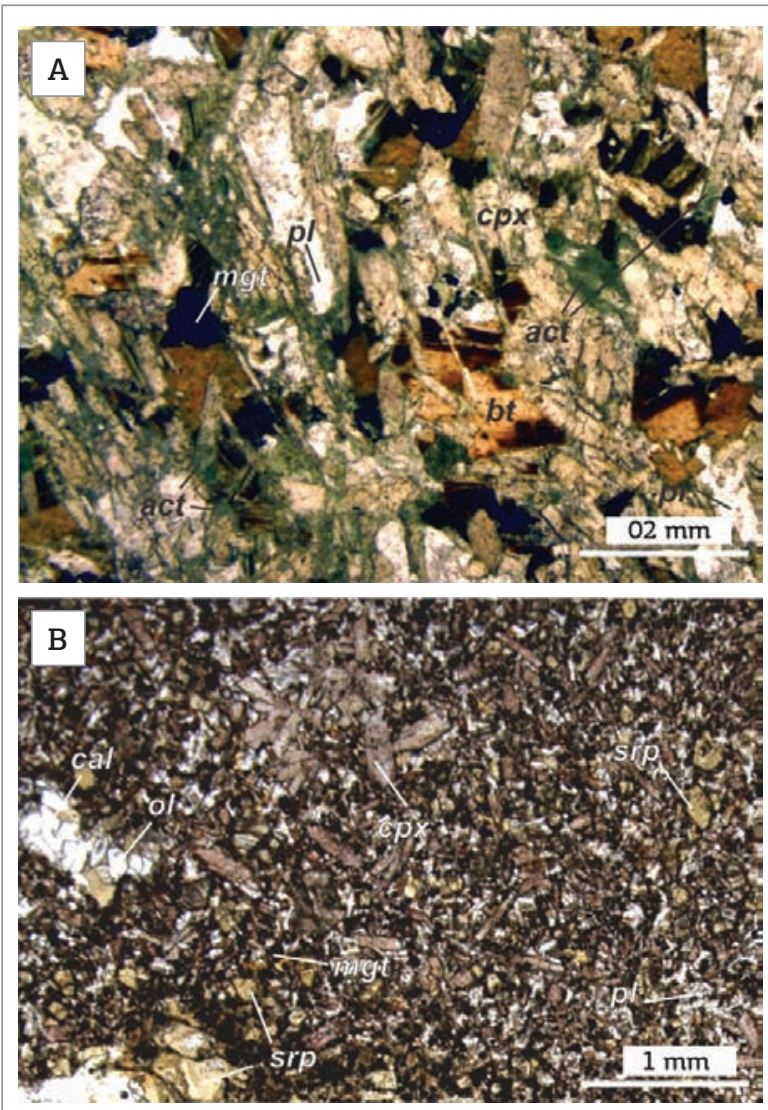

act: actinolite; bt: biotite; cal: calcite; cpx: clinopyroxene; mgt: magnetite; ol: olivine; pl: plagioclase; srp: serpentine.

Figure 4. Photomicrographs of the main products of deuteric/hydrothermal alteration in the studied dykes. (A) Actinolite associated with augite alteration, dyke 1 . (B) Pseudomorphs of olivine replaced by serpentine.

minor (wt.\%), and trace elements (ppm). These dykes are typically alkaline, with $\mathrm{SiO}_{2}$ contents ranging from 40.8 to $45.4 \mathrm{wt} . \%$ and alkalis ranging from 4.3 to 7.1 wt.\% (Fig. 5), and they are classified as basanite to tephrite. Dyke 2 shows the highest degree of silica under-saturation, with the highest contents of alkalis (6.3 to 7.1 wt.\%). Dyke 1 presents the lowest $\mathrm{SiO}_{2}$ levels (< 40.9 wt.\%), highest $\mathrm{TiO}_{2}$ values (4.4 to $5.2 \mathrm{wt} . \%$ ), and highest $\mathrm{CaO} / \mathrm{Al}_{2} \mathrm{O}_{3}$ ratios (1.9 to 1.8). Samples from dyke 3 have the highest $\mathrm{MgO}$ contents (12.2 to $13.8 \mathrm{wt} . \%$ ), and dyke 4 has the lowest $\mathrm{Fe}_{2} \mathrm{O}_{3 \mathrm{~T}}$ values (12.0 to $12.4 \mathrm{wt}$.\%).

Samples from the center and border of a given dyke provide subtle variations, especially in dykes 1 and 4 . Higher $\mathrm{MgO}$ (11.7 wt.\%) and $\mathrm{K}_{2} \mathrm{O}$ (3.0 wt.\%) contents occur in the center of dyke 1 compared to the border (7.5 and $2.6 \mathrm{wt} . \%$, respectively). The other major analyzed elements show lower contents in the center of the dyke than in the border. Such variations are petrographically associated with the greater amount of modal olivine and biotite in the center. Similarly, there are higher $\mathrm{MgO}$ amounts in the center (10.6 wt.\%) than in the border (7.8 wt.\%) of dyke 4 . This variation is apparently also associated with the greatest modal concentration of olivine megacrysts in the center.

Composition of all dykes shows positive correlations between $\mathrm{MgO}$ and $\mathrm{Cr}$ and between $\mathrm{Ni}$ and $\mathrm{Co}$, with greater concentration in the centers than in the borders. Such behavior suggests olivine, chrome-spinel, and clinopyroxene fractionation. The compositions also suggest negative correlations between $\mathrm{MgO}$ and $\mathrm{Ba}, \mathrm{Rb}, \mathrm{Pb}, \mathrm{Nb}, \mathrm{Zr}$, $\mathrm{Sr}$ and rare earth elements (REEs). High concentrations of $\mathrm{Ba}$ (> $1500 \mathrm{ppm}$ ) occur in dykes 1, 2 and 3, and of $\mathrm{Zr}$ (> $315 \mathrm{ppm}$ ) in dykes 1 and 3. The first dyke features the greatest REE concentrations (> $420 \mathrm{ppm}$ ), whereas dyke 4 presents the smallest ones ( $<326 \mathrm{ppm})$. Similar $\mathrm{Nb}, \mathrm{Pb}$ and Sr contents are observed in the studied dykes.

In all dykes, the distribution of REEs normalized by the chondrite shows a relatively linear behavior pattern, featuring more conspicuous enrichment in light REEs than in heavy ones (Fig. 6). Specifically, dyke 4 has greater enrichment in heavy REEs, with $\mathrm{La} / \mathrm{Yb}$ ratios ranging from 36.0 to 36.8 , and the 1 features the greatest enrichment in light REEs, with $\mathrm{La} / \mathrm{Yb}$ ratios varying from 65 to 80 . Only dykes 1 and 3 exhibit changes in REE enrichment among their samples, for example, a sample from the border of dyke 1 is slightly REE-enriched than a sample from its center. These variations are due to the differences in the proportion of megacrysts in both cases.

\section{DISCUSSION}

The mineralogical and geochemical compositions of monchiquites and camptonites in this study are mostly similar to those reported for the dyke swarms, in the alkaline provinces of Serra do Mar (Alves et al. 1992; Garda et al. 1995; Valente 1997; Thompson et al. 1998; Azzone et al. 2009; Enrich et al. 2009) and Arco de Ponta Grossa (Beccaluva et al. 1992; Gibson et al. 1999; Gomes et al. 2011). The megacryst and microcryst assemblages essentially consist of olivine, augite, titanaugite, biotite, titanomagnetite and kaersutite, similar to other aforementioned regional dykes.

Evaluation of the chemical equilibrium relationships between the megacrysts, microcrysts, and matrix of the dykes is ultimately paramount to understanding the geochemical analyses, especially whether the results are associated with the composition of magmatic liquids or represent liquids with crystals accumulation. MELTS thermodynamic models of crystallization (Ghiorso \& Sack 1995; Asimow \& Ghiorso 1998) were applied to study the liquid evolution trends and to determine the crystallization sequences. The initial compositions selected for the models correspond to those of the borders of dykes 1,2 and 4. The equilibrium crystallization 
Table 3. Whole-rock geochemical compositions (major, minor, and trace elements) of the studied alkaline lamprophyre dykes.

\begin{tabular}{|c|c|c|c|c|c|c|c|c|c|c|c|c|c|c|}
\hline \multirow[b]{2}{*}{ Position } & \multicolumn{2}{|c|}{ Dyke 1} & \multicolumn{6}{|c|}{ Dyke 2} & \multicolumn{4}{|c|}{ Dyke 3} & \multicolumn{2}{|c|}{ Dyke 4} \\
\hline & c & $\mathbf{b}$ & c & c & c & $\mathbf{b}$ & $\mathbf{b}$ & b & bl & bl & bl & bl & c & $\mathbf{b}$ \\
\hline Geochem. Class. & Basn. & basn. & tefr. & tefr. & tefr. & tefr. & tefr. & tefr. & basn. & basn. & basn. & basn. & basn. & basn. \\
\hline $\mathrm{SiO}_{2}$ (wt. \%) & 40.82 & 40.86 & 44.61 & 44.66 & 44.56 & 45.39 & 45.41 & 45.01 & 43.69 & 43.56 & 43.63 & 43.57 & 41.15 & 41.65 \\
\hline $\mathrm{TiO}_{2}$ & 4.38 & 5.23 & 3.05 & 3.03 & 3.10 & 2.91 & 2.97 & 2.97 & 3.65 & 3.64 & 3.64 & 3.82 & 3.01 & 3.15 \\
\hline $\mathrm{Al}_{2} \mathrm{O}_{3}$ & 6.25 & 7.11 & 12.49 & 12.36 & 12.41 & 13.18 & 13.16 & 12.79 & 8.36 & 8.36 & 8.27 & 8.72 & 11.50 & 12.80 \\
\hline $\mathrm{Fe}_{2} \mathrm{O}_{3}$ & 15.92 & 16.51 & 13.26 & 13.29 & 13.46 & 12.44 & 12.58 & 12.69 & 14.15 & 14.13 & 14.25 & 14.26 & 12.40 & 12.04 \\
\hline $\mathrm{MnO}$ & 0.27 & 0.61 & 0.20 & 0.20 & 0.20 & 0.19 & 0.19 & 0.20 & 0.19 & 0.19 & 0.19 & 0.19 & 0.17 & 0.17 \\
\hline $\mathrm{MgO}$ & 11.65 & 7.45 & 7.15 & 7.68 & 7.34 & 6.50 & 6.30 & 6.87 & 13.55 & 13.67 & 13.84 & 12.15 & 10.63 & 7.82 \\
\hline $\mathrm{CaO}$ & 11.71 & 12.83 & 10.08 & 10.14 & 10.18 & 9.52 & 9.61 & 9.79 & 9.69 & 9.67 & 9.72 & 10.92 & 10.35 & 10.59 \\
\hline $\mathrm{Na}_{2} \mathrm{O}$ & 1.43 & 2.49 & 3.15 & 3.33 & 3.14 & 3.58 & 3.60 & 3.67 & 2.15 & 2.14 & 2.14 & 2.02 & 2.08 & 2.37 \\
\hline $\mathrm{K}_{2} \mathrm{O}$ & 3.01 & 2.57 & 3.19 & 3.1 & 3.16 & 3.45 & 3.46 & 3.31 & 2.83 & 2.83 & 2.80 & 2.49 & 2.18 & 2.49 \\
\hline $\mathrm{P}_{2} \mathrm{O}_{5}$ & 0.67 & 0.81 & 0.58 & 0.55 & 0.57 & 0.57 & 0.57 & 0.60 & 0.56 & 0.56 & 0.57 & 0.80 & 0.75 & 0.82 \\
\hline LOI & 2.42 & 2.70 & 0.70 & 0.76 & 0.73 & 0.78 & 0.80 & 0.84 & $<0.01$ & 0.14 & 0.10 & $<0.01$ & 4.91 & 5.78 \\
\hline Total & 98.8 & 99.39 & 98.74 & 99.61 & 99.34 & 98.99 & 99.08 & 99.29 & 98.95 & 99.03 & 99.28 & 99.08 & 99.14 & 99.68 \\
\hline $\mathrm{mg} \#^{1}$ & 64.1 & 52.5 & 57.3 & 59.0 & 57.6 & 56.6 & 55.6 & 57.5 & 70.7 & 70.5 & 70.6 & 67.8 & 62.9 & 56.3 \\
\hline $\mathrm{Rb}$ (ppm) & 125 & 104 & 70 & 67 & 69 & 75 & 75 & 69 & 63 & 65 & 64 & 56 & 53 & 61 \\
\hline $\mathrm{Ba}$ & 1565 & 1700 & 1577 & 1531 & 1604 & 1660 & 1638 & 1658 & 1063 & 1085 & 1055 & 897 & 948 & 981 \\
\hline $\mathrm{Sr}$ & 891 & 1206 & 1234 & 1172 & 1239 & 1303 & 1290 & 1276 & 965 & 998 & 979 & 1207 & 976 & 1127 \\
\hline $\mathrm{Pb}$ & 10.6 & 10.1 & 9.59 & 9.16 & 9.59 & 10.0 & 10.1 & 11.3 & 7.72 & 7.51 & 6.96 & 6.20 & 3.78 & 3.68 \\
\hline Th & 10.7 & 12.6 & 7.82 & 7.70 & 7.76 & 8.36 & 8.61 & 8.20 & 8.54 & 8.41 & 8.14 & 7.23 & 6.74 & 7.16 \\
\hline $\mathrm{U}$ & 2.99 & 2.62 & 1.61 & 1.60 & 1.59 & 1.75 & 1.77 & 1.68 & 1.84 & 1.82 & 1.76 & 1.95 & 1.63 & 1.63 \\
\hline $\mathrm{Zr}$ & 361 & 414 & 275 & 271 & 276 & 285 & 290 & 278 & 314 & 313 & 308 & 339 & 267 & 287 \\
\hline $\mathrm{Hf}$ & 8.55 & 10.28 & 6.74 & 6.65 & 6.71 & 6.83 & 6.89 & 6.69 & 7.71 & 7.67 & 7.42 & 7.87 & 6.44 & 6.18 \\
\hline $\mathrm{Y}$ & 24 & 28 & 218 & 21 & 22 & 21 & 23 & 22 & 27 & 26 & 26 & 31 & 25.3 & 26.7 \\
\hline $\mathrm{Nb}$ & 84 & 100 & 62 & 60 & 61 & 66 & 67 & 63 & 61 & 62 & 60 & 60 & 71.9 & 79.6 \\
\hline Sc & 36 & 43 & 29 & 32 & 29 & 29 & 29 & 28 & 28.5 & 27.7 & 30 & 28.4 & 25 & 25 \\
\hline $\mathrm{Cr}$ & 946 & 192 & 195 & 222 & 201 & 167 & 160 & 186 & 880 & 842 & 842 & 741 & 403 & 366 \\
\hline $\mathrm{Ni}$ & 397 & 125 & 98 & 110 & 103 & 86 & 77 & 90 & 468 & 456 & 466 & 381 & 227 & 113 \\
\hline Co & 81 & 63 & 47 & 49 & 49 & 42 & 41 & 42 & 66 & 67 & 65 & 59 & 48 & 45 \\
\hline $\mathrm{V}$ & 386 & 479 & 320 & 326 & 343 & 310 & 309 & 304 & 306 & 284 & 305 & 302 & 223 & 236 \\
\hline $\mathrm{Ga}$ & 17 & 16 & 18 & 19 & 20 & 18 & 17 & 19 & 19 & 18 & 18 & 17 & 17 & 20 \\
\hline $\mathrm{Zn}$ & 110 & 118 & 96 & 93 & 98 & 93 & 93 & 92 & 106 & 109 & 108 & 112 & 102 & 104 \\
\hline $\mathrm{Cu}$ & 177 & 205 & 102 & 101 & 107 & 86 & 87 & 99 & 153 & 114 & 98 & 106 & 42 & 45 \\
\hline $\mathrm{La}$ & 94 & 117 & 82 & 79 & 81 & 85 & 87 & 86 & 72 & 71 & 70 & 77 & 61.6 & 64.8 \\
\hline $\mathrm{Ce}$ & 184 & 230 & 160 & 158 & 164 & 165 & 169 & 171 & 149 & 147 & 144 & 166 & 124 & 130 \\
\hline $\operatorname{Pr}$ & 22.6 & 28.5 & 19.3 & 18.6 & 19.2 & 19.6 & 19.9 & 20.0 & 17.5 & 17.4 & 17.0 & 20.1 & 14.9 & 15.4 \\
\hline $\mathrm{Nd}$ & 83.9 & 105.9 & 71.3 & 69.1 & 70.8 & 71.3 & 72.7 & 73.6 & 66.4 & 65.8 & 64.5 & 77.9 & 58.1 & 59.7 \\
\hline $\mathrm{Sm}$ & 13.0 & 16.4 & 11.3 & 11.0 & 11.3 & 11.2 & 11.3 & 11.5 & 11.8 & 11.7 & 11.4 & 14.1 & 10.6 & 10.7 \\
\hline $\mathrm{Eu}$ & 3.38 & 4.21 & 3.13 & 3.06 & 3.14 & 3.07 & 3.18 & 3.22 & 3.24 & 3.21 & 3.12 & 3.83 & 3.17 & 3.14 \\
\hline $\mathrm{Gd}$ & 9.2 & 11.92 & 8.26 & 7.93 & 8.1 & 7.94 & 8.13 & 8.1 & 9.12 & 8.83 & 8.82 & 10.87 & 8.43 & 8.54 \\
\hline $\mathrm{Tb}$ & 1.06 & 1.38 & 0.96 & 0.93 & 0.96 & 0.93 & 0.97 & 0.97 & 1.16 & 1.15 & 1.13 & 1.38 & 1.13 & 1.15 \\
\hline Dy & 4.96 & 6.48 & 4.69 & 4.57 & 4.7 & 4.61 & 4.72 & 4.73 & 5.65 & 5.53 & 5.44 & 6.6 & 5.78 & 5.84 \\
\hline Ho & 0.79 & 1.05 & 0.79 & 0.77 & 0.8 & 0.78 & 0.8 & 0.8 & 0.96 & 0.95 & 0.93 & 1.14 & 1.01 & 1.01 \\
\hline $\mathrm{Er}$ & 1.8 & 2.37 & 1.95 & 1.92 & 1.96 & 1.92 & 1.97 & 1.99 & 2.24 & 2.24 & 2.18 & 2.65 & 2.51 & 2.5 \\
\hline $\mathrm{Tm}$ & 0.22 & 0.29 & 0.25 & 0.24 & 0.25 & 0.25 & 0.25 & 0.25 & 0.27 & 0.27 & 0.27 & 0.32 & 0.3 & 0.3 \\
\hline $\mathrm{Yb}$ & 1.17 & 1.51 & 1.44 & 1.44 & 1.45 & 1.49 & 1.5 & 1.49 & 1.54 & 1.56 & 1.51 & 1.83 & 1.76 & 1.76 \\
\hline $\mathrm{Lu}$ & 0.18 & 0.22 & 0.23 & 0.22 & 0.23 & 0.23 & 0.23 & 0.23 & 0.23 & 0.22 & 0.22 & 0.27 & 0.25 & 0.25 \\
\hline
\end{tabular}

Abbreviations: c, center; b, border; bl, block; basn., basanite; tefr., tephrite. Geochemical classification according to Le Maitre (2002).

${ }^{1} \mathrm{mg} \#=\mathrm{MgO} /(\mathrm{MgO}+\mathrm{FeOt})$ molar 
conditions were evaluated in them. The initial temperature ( $\sim 1,200$ to $1,150^{\circ} \mathrm{C}$ ) was estimated based on the pyroxene saturation thermometer (Putirka 2008). A low-pressure condition ( $\mathrm{P}=1 \mathrm{kbar}$ ) was also assumed, as pointed out by Beccaluva et al. (1992) and Morbidelli et al. (1995). Several previous tests, similarly to those reported by Trumbull et al. (2003), were applied to establish the best oxygen fugacity conditions. In all situations, the crystallization sequence compatible with the petrographic observations was found applying $\mathrm{fO}_{2}=\mathrm{QFM}$.

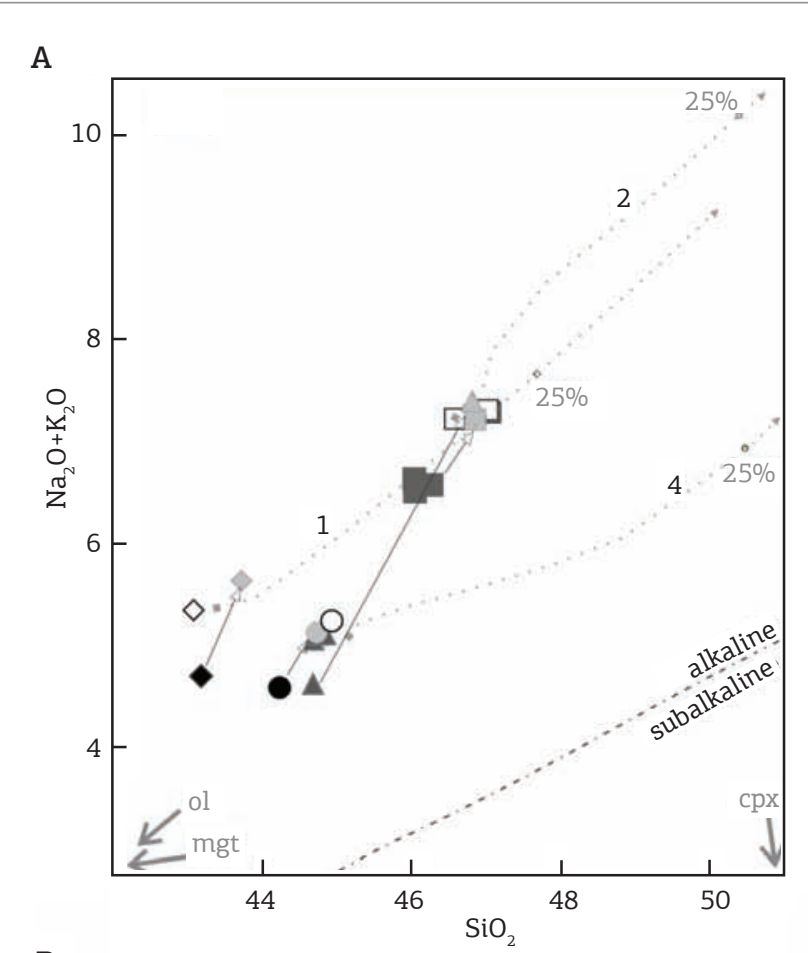

B

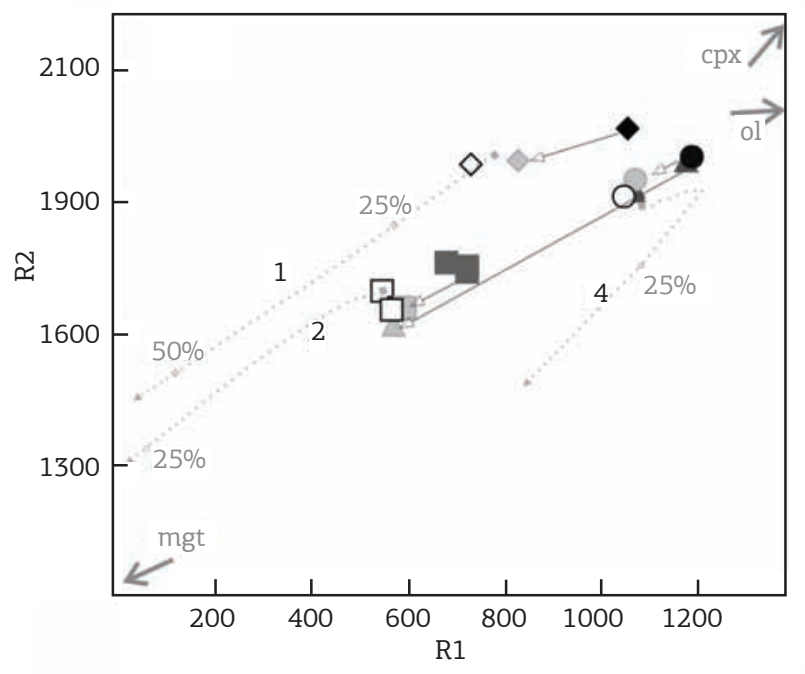

C

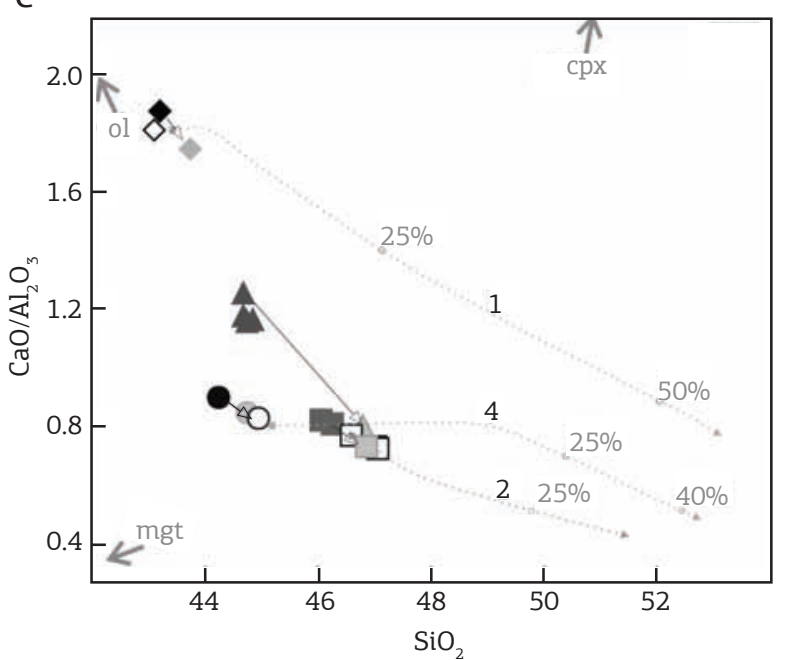

D
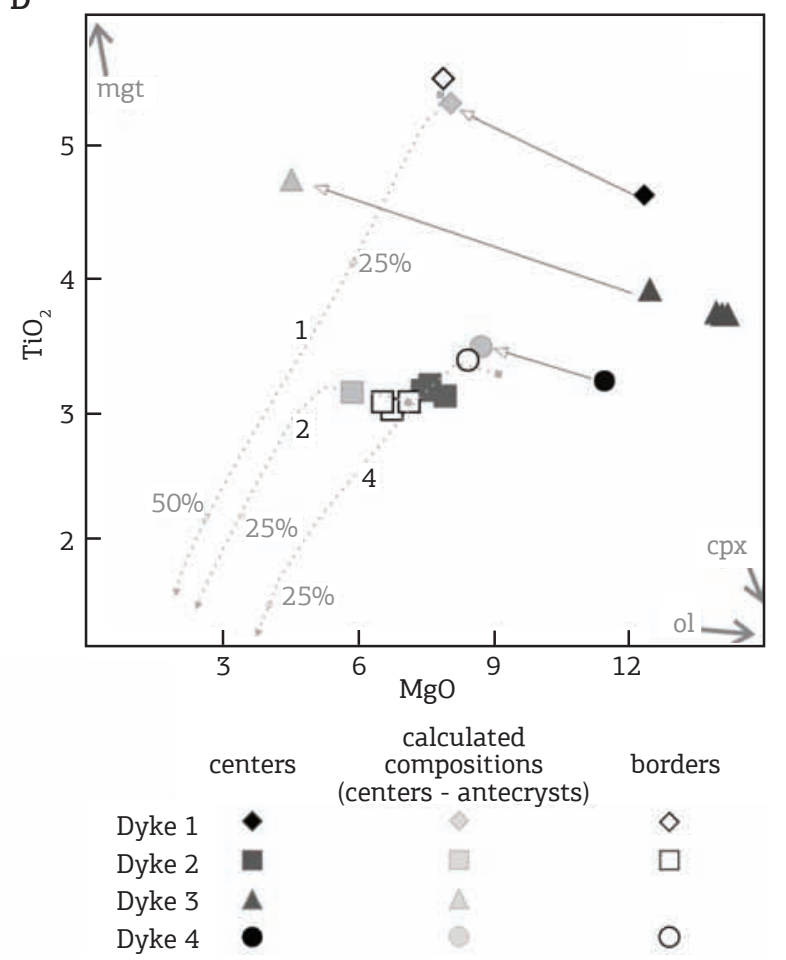

Dark and white symbols are used to indicate the compositions of the centers and borders of dykes, respectively. Compositional calculations subtracting the compositions of antecryst volumes from the whole-rock compositions of the center of the dykes are also shown in light gray. The continuous black-line arrows connect specific samples from the centers of dykes with their respective calculations. The mean compositions of the antecrysts (cpx: clinopyroxene; ol: olivine; mgt: magnetite) were compiled from Beccaluva et al. (1992) and Azzone (2008). Dotted grey lines: models of equilibrium crystallization performed using the MELTS algorithm for initial liquid compositions, calculated based on the compositions of the borders of dykes 1 , 2 , and 4. The numerical indications in these lines refer to the percentage of crystallization of the system. The conditions inferred for those models are $\mathrm{T}_{\text {initial }} \sim 1200^{\circ} \mathrm{C}, \mathrm{P}=1 \mathrm{kbar}, \mathrm{fO}_{2}=\mathrm{QFM}$. The data were recalculated for anhydrous basis in all diagrams.

Figure 5. (A) $\mathrm{SiO}_{2}$ versus $\left(\mathrm{Na}_{2} \mathrm{O}+\mathrm{K}_{2} \mathrm{O}\right)$ diagram with alkaline and subalkaline fields from Middlemost (1975). (B) R1 versus $\mathrm{R} 2$ diagram from De La Roche et al. (1980). (C) $\mathrm{CaO} / \mathrm{Al}_{2} \mathrm{O}_{3}$ versus $\mathrm{SiO}_{2}$ diagram. (D) $\mathrm{TiO}_{2}$ versus $\mathrm{MgO}$ diagram. 


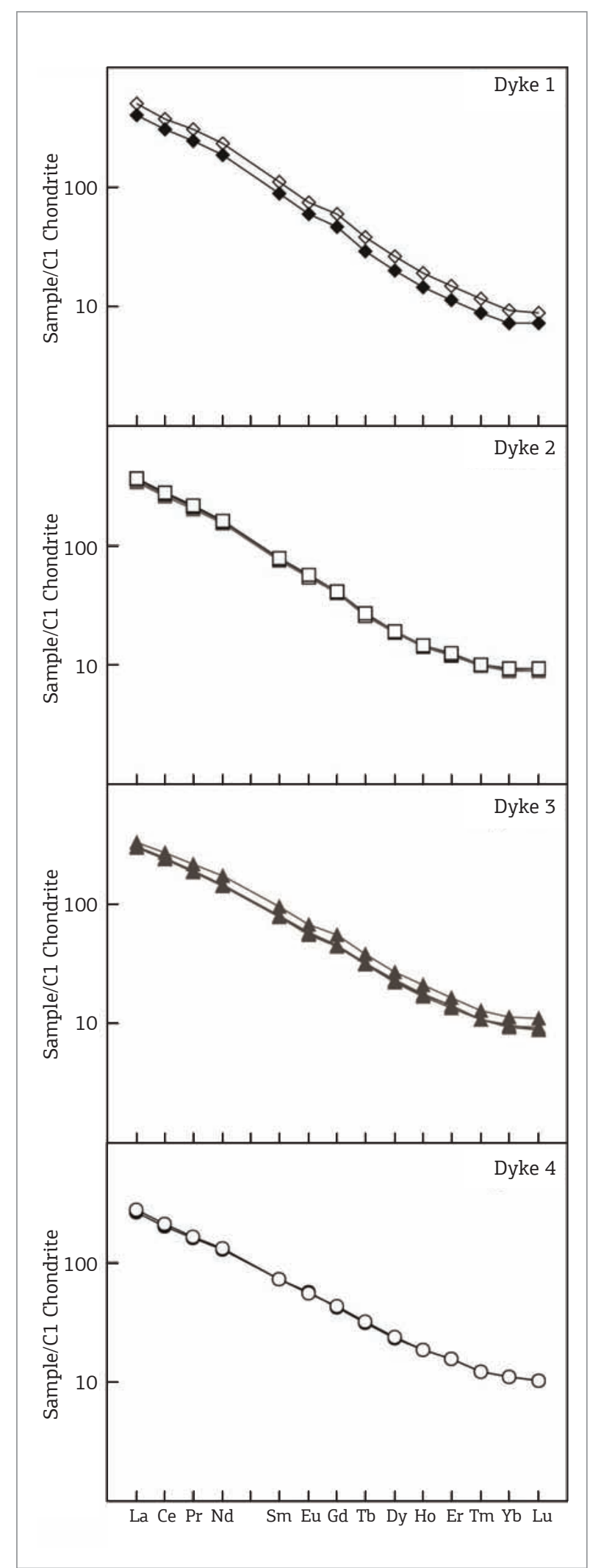

Figure 6. REE distribution patterns of the studied dykes normalized to the C1-chondrite (McDonough \& Sun 1995). Symbols as in Fig. 5.
In agreement with petrographic remarks, the early-crystallized phases in all applied MELTS models are olivine, spinel, and clinopyroxene. Trends of the liquids regarding each dyke usually evolve in parallel with progressive decreases in the amounts of $\mathrm{MgO}, \mathrm{TiO}_{2}$ and $\mathrm{CaO}$ and, subordinately, increases in $\mathrm{SiO}_{2}, \mathrm{Al}_{2} \mathrm{O}_{3}$ and alkalis $\left(\mathrm{K}_{2} \mathrm{O}\right.$ and $\mathrm{Na}_{2} \mathrm{O}$; Fig. 5) concentrations. The comparison of evolutionary modeled trends and the whole-rock geochemical data indicate that the samples of each studied dyke are representative of the combination of a magmatic liquid with accumulation of crystals.

However, the aforementioned petrographic features of megacryst population and part of microcryst assemblage (Fig. 2) preclude their classification as phenocrysts. The microtextures that enable this interpretation are as follows: zoned clinopyroxene megacrysts (augite cores and titanaugite rims), with partly corroded cores and features suggesting chemical resorption with the rock matrix; olivine crystals with corroded rims surrounded by biotite coronas; inclusions of oxide crystals (chrome-spinel) in clinopyroxene and olivine megacryst cores; and Ti-magnetite crystals surrounded by biotite coronas when in contact with the matrix.

Thus, these crystals are interpreted as antecrysts, i.e. minerals that were not crystallized from the host magma, but having a genetic linkage to the same magmatic system (Charlier 2005; Davidson et al. 2007; Ubide et al. 2012; Larrea et al. 2012). They could represent recycled crystals of earlier stages of the magmatic system at depth. The presence of clusters of clinopyroxene and olivine megacrysts in all dykes may be representative of autoliths associated with earlier magma chamber stages. Another interpretation treating these minerals as xenocrysts concerning the main cumulus phases (olivine and clinopyroxene) incorporated from cumulate alkaline wall rocks would also fit the petrographic evidence for the megacrysts from dykes 2 and 3. However, even if this was the case, the term 'antecrysts' may also be understandably applied since these dykes are genetically linked to the evolution of plutonic bodies.

In particular, the modal proportions of antecrysts are correlated with geochemical compositional variations between the center and border zones of each body. The greatest geochemical differences between the center and border zones are seen in the dykes with the greatest cargo of megacrysts (dykes 1 and 4).

Thus, populations of crystals with disequilibrium textures were subtracted from the whole-rock compositions of the dyke centers in order to try to understand the significance of the zonation patterns between the bodies and the influence of these antecrysts on the geochemical composition of the rocks. The calculation was performed applying the following equation (Ubide et al. 2012): 
$\mathrm{C}_{\mathrm{WR}}{ }^{\mathrm{i}}=\mathrm{C}_{\mathrm{Mt}}{ }^{\mathrm{i}}\left(1-\sum \mathrm{v}\right)+\sum\left(\mathrm{C}_{\mathrm{Atc}}{ }^{\mathrm{i}}+\mathrm{v}\right)$

where, $\mathrm{C}_{\mathrm{WR}}{ }^{\mathrm{i}}, \mathrm{C}_{\mathrm{Mt}}{ }^{\mathrm{i}}$ and $\mathrm{C}_{\mathrm{Atc}}{ }^{\mathrm{i}}$ are the concentrations of the element $i$ in the whole-rock, matrix and antecrysts, respectively, and $v$ is the modal volume of the antecrysts. The antecrysts refer to olivine and clinopyroxene ratios and subordinately oxide (opaque) ones. These crystals are somewhat unstable in the matrix or isolated if included in other minerals. The mineral chemical data required for this calculation were compiled from Beccaluva et al. (1992) and Azzone (2008). The estimated ratios of antecrysts for each case and the results of these calculations are displayed in Tab. 4.

The results obtained through the geochemical modeling show that there are key changes in the calculated compositions regarding the whole-rock analyses. These calculated compositions are usually more evolved than the whole-rock compositions, i.e. the antecryst cargo makes the whole-rock composition of the dykes more "primitive". The antecryst cargo enriches it in $\mathrm{MgO}, \mathrm{FeO}, \mathrm{TiO}_{2}$ and $\mathrm{CaO}$ and, therefore, depletes it in $\mathrm{SiO}_{2}, \mathrm{~K}_{2} \mathrm{O}, \mathrm{Na}_{2} \mathrm{O}$ and $\mathrm{Al}_{2} \mathrm{O}_{3}$. The highest differences between calculated and whole-rock compositions are associated with dyke 3, which has the greatest proportion of megacrysts. Overlap occurs between the calculated compositions of dykes 2 and 3, suggesting rather similar liquids (Fig. 5 and Tab. 4).
For the trace-element behavior, a greater antecryst cargo favors the enrichment in $\mathrm{Cr}, \mathrm{Ni}$, and $\mathrm{Co}$ (Fig. 7), with compatible elements with the antecryst structures (Azzone et al. 2013). Conversely, incompatible elements with those structures, including $\mathrm{Ba}$ and $\mathrm{Sr}$, tend to have decreased concentrations due to the greater cargo of this assemblage (Fig. 7). Furthermore, differences in REE concentrations (Fig. 6) found for dyke 1 may be explained more specifically due to the higher ratio of olivine antecrysts, a structure in which REEs exhibit extremely incompatible behavior (Azzone et al. 2013). Similarly, element concentrations of dyke 3 differ between individual samples, and these variations concern the olivine antecryst population of each one.

There is a great similarity and even overlap in the calculated compositions (i.e. the compositions of the dyke centers minus the antecryst assemblage compositions) and the whole-rock compositions of the borders for dykes 1, 2 and 4 (Tab. 4 and Fig. 5). Based on this evidence, geochemical compositional variations associated with zoning of each body may not be easily attributed to liquid fractionation by magmatic flow; that is, no compositional differences of the magmatic liquid occur within the dyke conduit. Conversely, each studied body may be understandably a representation of single magmatic liquid, with variable amounts of antecrysts in different zones.

Table 4. Calculated bulk compositions based on the analyses of dyke centers minus the estimated antecryst ratios for each case.

\begin{tabular}{|c|c|c|c|c|c|c|c|}
\hline & \multicolumn{2}{|c|}{ Dyke 1} & \multicolumn{2}{|c|}{ Dyke 2} & \multirow{2}{*}{$\begin{array}{l}\text { Dyke } 3 \\
\text { bl rec. }\end{array}$} & \multicolumn{2}{|c|}{ Dyke 4} \\
\hline & c rec. & b & c rec. & b & & c rec. & b \\
\hline \multicolumn{8}{|c|}{ Ratios of antecrysts } \\
\hline$\%$ ol & 11 & & 3 & & 15 & 7 & \\
\hline$\%$ сpx & 5 & & 5 & & 20 & 3 & \\
\hline \%mgt & 0.5 & & 1 & & 3 & 0.3 & \\
\hline $\mathrm{SiO}_{2}$ (wt. \%) & 43.7 & 43.1 & 46.8 & 47.0 & 46.8 & 44.7 & 44.9 \\
\hline $\mathrm{TiO}_{2}$ & 5.3 & 5.5 & 3.2 & 3.0 & 4.8 & 3.5 & 3.4 \\
\hline $\mathrm{Al}_{2} \mathrm{O}_{3}$ & 7.7 & 7.5 & 14.0 & 13.7 & 13.3 & 13.8 & 13.8 \\
\hline $\mathrm{FeO}_{\mathrm{T}}$ & 14.9 & 15.7 & 11.8 & 11.6 & 11.1 & 11.4 & 11.7 \\
\hline $\mathrm{MnO}$ & 0.3 & 0.6 & 0.2 & 0.2 & 0.1 & 0.2 & 0.2 \\
\hline $\mathrm{MgO}$ & 8.0 & 7.9 & 5.9 & 6.7 & 4.5 & 8.7 & 8.4 \\
\hline $\mathrm{CaO}$ & 13.5 & 13.5 & 10.2 & 9.9 & 10.6 & 11.7 & 11.4 \\
\hline $\mathrm{Na}_{2} \mathrm{O}$ & 1.8 & 2.6 & 3.6 & 3.7 & 3.2 & 2.5 & 2.6 \\
\hline $\mathrm{K}_{2} \mathrm{O}$ & 3.8 & 2.7 & 3.6 & 3.6 & 4.2 & 2.6 & 2.7 \\
\hline $\mathrm{P}_{2} \mathrm{O}_{5}$ & 0.9 & 0.9 & 0.7 & 0.6 & 1.3 & 0.9 & 0.9 \\
\hline Total & 100.0 & 100.0 & 100.0 & 100.0 & 100.0 & 100.0 & 100.0 \\
\hline Geochem. Class. & Basanite & Basanite & Tephrite & Tephrite & Tephrite & Basanite & Basanite \\
\hline
\end{tabular}

The estimates of the antecryst ratios in each region are qualitative and based on petrographic and modal analyses. The results are shown and compared with the compositional data of the dyke border samples, both recalculated on an anhydrous basis. c: center; b: border; bl: block; rec.: recalculated. 


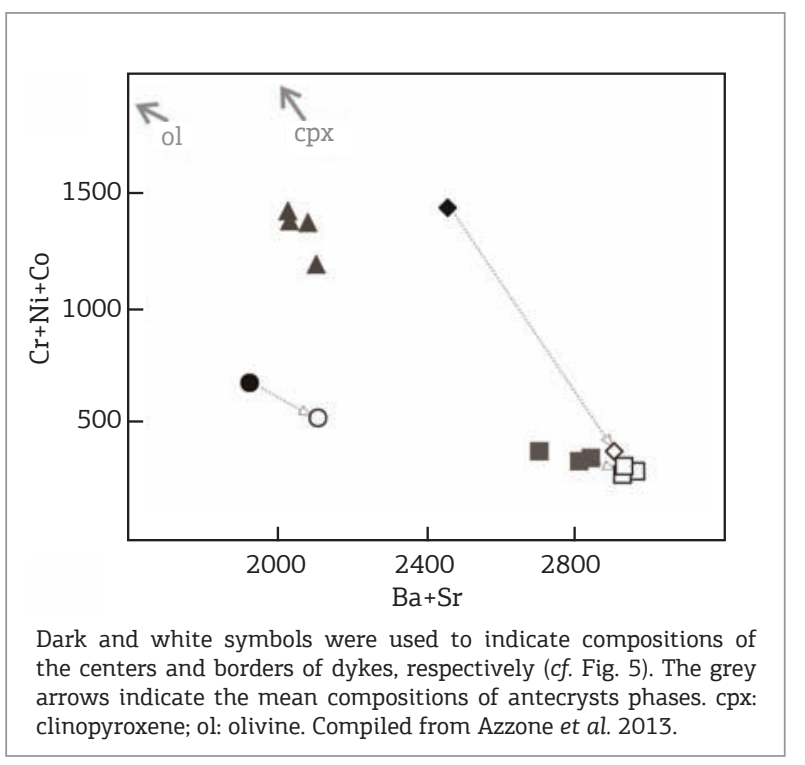

Figure 7. Trace elements compositional variations of the studied dykes.

The varieties in alkali enrichment and $\mathrm{SiO}_{2}$-undersaturation between the studied bodies are apparently associated with differences in the initial compositions. This relation is evidenced by the parallel trajectories of fractional crystallization between dykes (Fig. 5) and the common early mineral assemblage. In addition to the diversifications in the degree of $\mathrm{SiO}_{2}$-undersaturation between the dykes, the first dyke exhibits a $\mathrm{CaO} / \mathrm{Al}_{2} \mathrm{O}_{3}$ ratio near 2, whereas dykes 2, 3 and 4 have values near 1 (Fig. 5). Discrepancies in this ratio have been explained due to source heterogeneity. Values of the $\mathrm{CaO} / \mathrm{Al}_{2} \mathrm{O}_{3}$ ratio $>1$ may be associated with a greater abundance of metasomatic clinopyroxene in the source (Gibson et al. 1999). Such increase in Ca concentration also follows experimental reactions of a dolomitic fluid with orthopyroxene under mantle conditions (Dalton \& Wood 1993), thus suggesting carbonatic metasomatism in the source. Greater $\mathrm{CaO} / \mathrm{Al}_{2} \mathrm{O}_{3}$ ratios in the studied samples correspond to smaller amounts of $\mathrm{SiO}_{2}$, corroborating the reactions proposed in the experimental studies.

A possible scenario for the generation of lamprophyres in this region involves the vein-plus-wall-rock melting model detailed by Foley (1992). In such case, variations in the degree of undersaturation and magma enrichment would also be associated with the slightly modified signatures of mantle wall rock involved in the process, and the variable melting degrees associated with the metasomatic veins. Azzone et al. (2013) apply this model to different basanitic compositions in equilibrium with cumulates of the Juquiá alkaline complex, and they describe the possible effects of carbonatic metasomatism at a local scale. The detailed study of the selected dykes suggests greater variations at a regional scale, with different trace element signatures between the provinces Serra do Mar and Arco de Ponta Grossa, as already reported in previous studies (Gibson et al. 1999; Ruberti et al. 2012).

\section{CONCLUSIONS}

The studied alkaline lamprophyre dykes present a significant antecryst cargo, mainly observed at the dyke centers. The antecryst assemblage includes olivine, augite, and spinel, always with instability features that include zoning, corroded cores, and coronitic textures. In fact, the antecrysts cargo proportionally modifies the whole-rock geochemical compositions assessed for different dyke zones. When the compositional influence of the antecrysts found in the centers of each occurrence was removed by mass-balance calculations, their compositions were very similar to the border zones. This evidence suggests that a single magmatic liquid forms each occurrence, and the textural and compositional differences between the centers and borders are mainly due to the cargo of antecrysts of each zone.

There are dissimilarities in the degree of $\mathrm{SiO}_{2}$-undersaturation with respect to each occurrence. However, the modeled crystallization sequences are very similar, involving early fractionation of the same minerals and parallel evolutionary trends. Thus, after subtracting the antecryst volume, the compositional differences observed between the lithotypes of each occurrence should be associated with others in the bulk composition of the mantle source and the greater or lesser effect of mantle metasomatism.

The alkaline lamprophyres represent rather complex systems. The bulk geochemical analysis of each dyke is much more representative of the combination of accumulated crystals and melt than solely representative of a melt. Thus, the antecryst compositional effects should not be ignored in petrological studies focused on discussions of the evolution of magmatic liquids. The importance of detailed petrographic studies for the identification of this assemblage is emphasized.

\section{ACKNOWLEDGMENTS}

This research study was funded by the Fundação de Amparo à Pesquisa do Estado de Sáo Paulo - FAPESP (processes n. 2010/20425-8, RGA; 2012/06082-6, ER; 2013/18073-4, CBG). This investigation reports data collected in the graduation monograph research of the first author (SGM), and with the help of scientific initiation scholarships provided by Programa Institucional de Bolsas de Iniciação Cientifica of Conselho Nacional de Desenvolvimento Cientifico e Tecnológico (PIBIC-CNPq). 


\section{REFERENCES}

Alves F.R., Ruberti E., Vlach S.R.F. 1992. Magmatismo meso-cenozóico da região da Serra da Mantiqueira, SP/MG. Boletim IG-USP, Publicação Especial, 12:7-9.

Asimow P.D. \& Ghiorso M.S. 1998. Algorithmic Modifications Extending MELTS to Calculate Subsolidus Phase Relations. American Mineralogist, 83:1127-1131.

Azzone R.G. 2008. Petrogênese do maciço máfico-ultramáfico Ponte Nova (SP-MG). PhD Thesis, Universidade de São Paulo, São Paulo, 240 p.

Azzone R.G., Enrich G.E.R., Gomes C.B., Ruberti E. 2013. Trace element composition of parental magmas from mafic-ultramafic cumulates determined by in situ mineral analyses: The Juquiá mafic-ultramafic alkaline-carbonatite massif, SE Brazil. Journal of South American Earth Sciences, 41:5-21.

Azzone R.G., Ruberti E., Enrich G.E.R., Gomes C.B. 2009. Geologia e geocronologia do maciço alcalino máfico-ultramáfico Ponte Nova (SP-MG). Geologia USP - Série Científica, 9:23-46.

Barbosa E.S.R., Brod J.A., Junqueira-Brod T.C., Dantas E.L., Cordeiro P.F.O., Gomide C.S. 2012. Bebedourite from its type area (Salitre I complex): a key petrogenetic series in the Late-Cretaceous Alto Paranaíba kamafugite carbonatite phoscorite association, Central Brazil. Lithos, 144-145:56-72.

Beccaluva L., Barbieri M., Born H., Brotzu P., Coltorti M., Conte A., Garbarino C., Gomes C.B., Macciotta G., Morbidelli L., Ruberti E., Siena F., Traversa G. 1992. Fractional Crystallization and Liquid Immiscibility processes in the Alkaline-Carbonatite Complex of Juquiá (Sao Paulo, Brazil). Journal of Petrology, 33(6):1371-1404.

Bellieni G., Montes Lauar C.R., De Min A., Piccrillo E.M., Cavazzini G., Melfi A.J., Pacca I.G. 1990. Early and late cretaceous magmatism from São Sebastião Island (SE - Brazil): Geochemistry and petrology. Geochimica Brasiliensis, 4(1):59-83.

Brod J.A., Junqueira-Brod T.C., Gaspar J.C., Petrinovic I.A., Valente S.C., Corval A. 2013. Decoupling of paired elements, crossover REE patterns, and mirrored spider diagrams: Fingerprinting liquid immiscibility in the Tapira alkaline carbonatite complex, SE Brazil. Journal of South American Earth Sciences, 41:41-56.

Brotzu P., Gomes C.B., Melluso L., Morbidelli L., Morra V., Ruberti E. 1997. Petrogenesis of coexisting $\mathrm{SiO}_{2}$-undersaturated to $\mathrm{SiO}_{2}$-oversaturated felsic igneous rocks: The alkaline complex of Itatiaia, southeastern Brazil. Lithos, 40(2-4):133-156.

Cavalcante J.C., Cunha H.C.S., Chieregati L.A., Kaefer L.Q., Rocha J.M., Daitx E.C., Coutinho M.G.N., Yamamoto K., Drumond J.B.V., Rosa D.B., Ramalho R. 1979. Projeto Sapucaí: Relatório Final de Geologia. Série Geologia, n. 5, Seção Geologia Básica, n. 2, Brasília: DNPM/CPRM. 299 p.

Charlier B.L.A., Wilson C.J.N., Lowenstern J.B., Blake S., Van Calsteren P.W., Davidson J.P. 2005. Magma generation at a large, hyperactive silicic volcano (Taupo, New Zealand) revealed by U-Th and U-Pb systematics in zircons. Journal of Petrology, 46(1):3-32.

Chayes F. 1956. Petrographic modal analysis - an elementary statistical appraisal. New York, John Wiley and Sons, 113 p.

Comin-Chiaramonti P., Cundari A., Piccirillo E.M., Gomes C.B., Castorina F., Censi P., de Min A., Marzoli A., Speziale S., Velázquez V.F., 1997. Potassic and Sodic Igneous Rocks from Eastern Paraguay: their Origin from the Lithospheric Mantle and Genetic Relationships with the Associated Paraná Flood Tholeiites. Journal of Petrology, 38(4):495-528.
Dalton J.A. \& Wood B.J. 1993. The compositions of primary carbonate melts and their evolution through wallrock reaction in the mantle. Earth and Planetary Science Letters, 119:511-525.

Davidson J.P., Morgan D.J., Charlier B.L.A., Harlou R., Hora J.M. 2007. Microsampling and isotopic analysis of igneous rocks: implications for the study of magmatic systems. Annual Review of Earth and Planetary Sciences, 35:273-311.

De La Roche H., Leterrier J., Grandclaude P., Marchal M. 1980. A classification of volcanic and plutonic rocksusing R1-R2 diagram and major-element analyses. Its relationships with current nomenclature. Chemical Geology, 29:183-210.

Enrich G.E.R., Ruberti E., Gomes C.B. 2009. Geology and geochronology of Monte de Trigo island alkaline suite, southeastern Brazil. Revista Brasileira de Geociências, 39:67-80.

Faleiros F.M. \& Pavan M. 2013. Geologia e Recursos Minerais da Folha Eldorado Paulista - SG-22-X-B-XI, estado de São Paulo, Escala: 1:100.000. São Paulo, Companhia de Pesquisa de Recursos Minerais, CPRM.

Foley A.F. 1984. Liquid immiscibility and melt segregation in alkaline lamprophyres from Labrador. Lithos, 17:127-137.

Foley S.F. 1992. Vein-plus-wall-rock melting mechanisms in the lithosphere and the origin of potassic alkaline magmas. Lithos, 28:435-453.

Garda G., Schorscher J.H.D., Esperança S., Carlson R.W. 1995. The Petrology and Geochemistry of Coastal Dikes from São Paulo State, Brazil: Implication for Variable Litospheric Contributions to Alkaline Magmas from the Western Margins of the South Atlantic. Anais da Academia Brasileira de Ciências, 67:191-216.

Ghiorso M.S. \& Sack R.O. 1995. Chemical Mass Transfer in Magmatic Processes. IV. A Revised and Internally Consistent Thermodynamic Model for the Interpolation and Extrapolation of Liquid-Solid Equilibria in Magmatic Systems at Elevated Temperatures and Pressures. Contributions to Mineralogy and Petrology, 119:197-212.

Gibson S.A., Thompson R.N., Leonardos O.H., Dickin A.P., Mitchell J.G. 1999. The limited extent of plumelitosphere interactions during continental flood-basalt genesis: geochemical evidence from Cretaceous magmatism in southern Brazil. Contributions to Mineralogy and Petrology, 137:147-169.

Gomes C.B., Ruberti E., Comin-Chiaramonti P., Azzone R.G. 2011. Alkaline magmatism in the Ponta Grossa Arch, SE Brazil: a review. Journal of South American Earth Sciences, 32:152-168.

Jerram D.A. \& Martin V.M. 2008. Understanding crystal populations and their significance through the magma plumbing system. In: Annen C. \& Zellmer G.F. (eds.) Dynamics of Crustal Magma Transfer, Storage and Differentiation. Geological Society Special Publications, London, 304, p. 133-148.

Larrea P., Franca Z., Lago M., Widom E., Gale C., Ubide T. 2012. Magmatic Processes and the Role of Antecrysts in the Genesis of Corvo Island (Azores Archipelago, Portugal). Journal of Petrology, 54(4):769-793.

Le Maitre R.W. 2002. Igneous rocks. A classification of igneous rocks and glossary of terms. 2 ed. Cambridge, Cambridge University Press, 236 p.

McDonough W.F. \& Sun S. 1995. The composition of the Earth. Chemical Geology, 120:223-253.

Middlemost E.A.K. 1975. The basalt clan. Earth Science Reviews, 11:337-364. 
Morbidelli L., Gomes C.B., Beccaluva L., Brotzu P., Conte A.M., Ruberti E., Traversa G. 1995. Mineralogical, petrological and geochemical aspects of alkaline and alkaline-carbonatite associations from Brazil. Earth Sciences Reviews, 39:135-168.

Mori P.E., Reeves S., Correia C.T., Haukka M. 1999. Development of a fused glass disc XRF facility and comparison with the pressed powder pellet technique at Instituto de Geociências, São Paulo University. Revista Brasileira de Geociências, 29(3):441-446.

Navarro M.S, Andrade S., Ulbrich H.H.J., Girardi V.V. 2008. The analysis of rare earth elements with ICP-MS in basaltic and related rocks: testing the efficiency of sample decomposition procedures. Geostandards and Geoanalytical Research, 32:167-180.

Parson I., Mason R.A., Becker S.M., Finch A.A. 1991. Biotite equilibria and fluid circulation in the Klokken intrusion. Journal of Petrology, 32:1299-1333.

Potts P.J. 1987. A handbook of Silicate Rock Analysis. New York, Blackie Academic \& Professional, 622 p.

Putirka K.D. 2008. Thermometers and Barometers for Volcanic Systems. Reviews in Mineralogy \& Geochemistry, 69:61-120

Riccomini C., Velázquez V.F., Gomes C.B. 2005. Tectonic controls of the Mesozoic and Cenozoic alkaline magmatism in the central-southeastern Brazilian Platform. In: Comin-Chiaramonti P. \& Gomes C.B. (eds.) Mesozoic to Cenozoic Alkaline Magmatism in the Brazilian Platform. Edusp/Fapesp, São Paulo, p. 31-55.

Rock N.M.S. 1991. Lamprophyres. Glasgow, Blackie Academic \& Professional, $285 \mathrm{p}$.

Ruberti E., Enrich G.E.R., Azzone R.G., Comin-Chiaramonti P., de Min A., Gomes C.B. 2012. The Banhadão alkaline complex, southeastern Brazil: source and evolution of potassic $\mathrm{SiO}_{2}$-undersaturated high-Ca and low-Ca magmatic series. Mineralogy and Petrology, 104:63-80.

Schobbenhaus C., Gonçalves J.H., Santos J.O.S., Abram M.B., Leão Neto R., Matos G.M.M., Vidotti R.M., Ramos M.A.B., Jesus J.D.A. 2004.
Carta Geológica do Brasil ao Milionésimo - Folha SF-23. Brasília, Companhia de Pesquisa de Recursos Minerais, CPRM.

Thompson R.N., Gibson S.A., Mitchell J.G., Dickin A.P., Leonardos O.H., Brod J.A., Greenwood J.C. 1998. Migrating Cretaceous-Eocene Magmatism in the Serra do Mar Alkaline Province, SE Brazil: Melts from the Deflected Trindade Mantle Plume? Journal of Petrology. 39(8):1493-1526.

Traversa G., Barbieri M.. Beccaluva L., Coltorti M., Conte A.M Garbarino C., Gomes C.B., Macciotta G., Morbidelli L., Ronca S. Scheibe L.F. 1996. Mantle sources and differentiation of alkaline magmatic suite of Lages, Santa Catarina, Brazil. European Journal of Mineralogy, 8(1):193-208.

Trumbull R.B., Buhn B., Romer R.L., Volker F. 2003. The Petrology of Basanite-Tephrite Intrusions in the Erongo Complex and Implications for a Plume Origin of Cretaceous Alkaline Complexes in Namibia. Journal of Petrology, 44(1):93-111.

Ubide T., Arranz E., Lago M., Galé C., Larrea P. 2012. The influence of crystal settling on the compositional zoning of a thin lamprophyre sill: a multi-method approach. Lithos, 132-133:37-49.

Ulbrich H.H.G.J., Vlach S.R.F., Demaiffe D., Ulbrich M.N.C. 2005 Structure and origin of the Poços de Caldas Alkaline Massif, SE Brazil. In: Comin-Chiaramonti P. \& Gomes C.B. (eds.) Mesozoic to Cenozoic Alkaline Magmatism in the Brazilian Plataform. São Paulo, Edusp/Fapesp, p. 367-418.

Valente S.C. 1997. Geochemical and isotopic constraints on the petrogenesis of the cretaceous dykes of Rio de Janeiro, Brazil. PhD Thesis, Queen's University of Belfast, Belfast, 366 p.

Vichi G., Stoppa F., Wall F. 2005. The carbonate fraction in carbonatitic Italian lamprophyres. Lithos, 85:154-170.

Arquivo digital disponível on-line no site www.sbgeo.org.br 